\title{
Evaluation of the yield and some components in the fruit of blue honeysuckle (Lonicera caerulea var. edulis Turcz. Freyn.)
}

\author{
Monika Małodobry, Monika Bieniasz, Ewa Dziedzic \\ Department of Pomology and Apiculture \\ Faculty of Horticulture, University of Agriculture in Krakow \\ 29 Listopada 54, 31-425 Kraków, Poland \\ e-mail: mmalodobry@ogr.ur.krakow.pl
}

\begin{abstract}
The experiment was carried out in the Garlica Murowana Experimental Station of University of Agriculture in Krakow, Poland, between 2005 and 2008. Fruit yield, mass of 100 berries, content of total soluble solids, vitamin C, anthocyanins and titratable acidity were estimated. It was shown that 'Atut' honeysuckle started vegetation, flowering and cropping periods earlier than 'Duet'. However, greater marketable yield and mass of 100 berries were obtained for 'Duet'. 'Atut' fruit revealed a significantly higher content of anthocyanins. The studied honeysuckle cultivars did not differ if estimated on the basis of total soluble solids and vitamin $\mathrm{C}$ content in the fruit.
\end{abstract}

Key words: mass of berries, anthocyanins, vitamin C

\section{INTRODUCTION}

A growing interest has been observed in cultivation and breeding of blue honeysuckle - Lonicera caerulea var. edulis Turcz. Freyn. The majority of Lonicera species have inedible or even poisonous fruit. The plants bearing edible fruit belong to the caerulea Red. section. There are many differing opinions on the number of species belonging to the Lonicera genus and subgenus caerulea (Plekhanova and Rostova 1994, Marková 2001). According to Solovyeva and Plekhanova (2003), the diploid and tetraploid forms of $L$. edulis are distinct karyotypes while the $2 \times$ and $4 \times$ races of the same species are not.

The bushes of that species have been cultivated since 1950. Wild material has been collected from Russia, Japan and China and it is now preserved at the United States Department of Agriculture, Agricultural Research Service, National Clonal Germplasm Repository in Corvallis, Oregon (Hummer 2006). Thompson introduced the Japanese selections to the U.S. in 2000 and is carrying out an outstanding breeding programme in Corvallis (Thompson and Chaovanalikit 2003). More recently, breeding work is also being carried out by Bors
(2009) at the University of Saskatchewan in Canada. Many experiments with honeysuckle are being carried out in the Czech and Slovak Republics (Antaliková et al. 2007) and in Estonia (Arus and Kask 2007).

Blue honeysuckle is a long-living bush, with the earliest ripening fruit at the end of May. According to Plekhanova $(1996,2000)$ the bushes of that species are tolerant to low temperatures $\left(-45^{\circ} \mathrm{C}\right)$, however, other authors also report that there was no injures of plants after a winter with frost and temperatures reaching $-35^{\circ} \mathrm{C}$ (Golis and Gwozdecki 2007). The flowers can withstand temperatures of even $-8^{\circ} \mathrm{C}$ and were not injured by low temperature during flowering. The dark purple fruit flesh is aromatic, juicy, sweet and sour, and their taste resembles that of bilberry. Sometimes the taste of the fruit is slightly bitter. The fruit are a valuable crop, mostly owing to the content of nutritional values (sugars, acids, macro and microelements) and anthocyanins (Małolepsza and Urbanek 2000, Kawecki et al. 2001, Lipecki et al. 2003, Thompson and Chaovanalikit 2003, Zadernowski et al. 2005, Misaki et al. 2006). The fruit extract has the benefit and promising effects of oncostatic therapy. L. caerulea extract reduced the tumour volume, when administrated 
continuously during the tumour growth and development progress (Gruia et al. 2008). The potential of L. caerulea berries to prevent chronic diseases such as diabetes mellitus, cardiovascular diseases and cancer seems to be related above all to their phenolic content (Svarcova et al. 2007). The major anthocyanins in L. caerulea fruit are glucosides and rutinosides like cyanidin, peonidin, dephinidin and pelargonidin. These berries seem to be prospective sources of health supporting phytochemicals that exhibit beneficial activities such as anti-adherence, antioxidant and chemoprotective, thus they may provide protection against a number of chronic conditions, e.g. cancer, diabetes mellitus, tumour growth or cardiovascular diseases (Svarcova et al. 2007). In Lonicera edulis the ratio of three anthocyanins, cyanidin3-glucoside, cyaniding-3,5-diglucoside, and peonidin -3,5-diclucoside, is 89:4:7 (Máriássyová et al. 1999).

The aim of the study was to evaluate the fruit yield, mass of the fruit and chemical composition (total soluble solids, titratable acidity, ascorbic acid, anthocyanins) of two honeysuckle cultivars, 'Atut' and 'Duet'.

\section{MATERIAL AND METHODS}

The bushes of 'Atut' and 'Duet' were planted in 2003 in the Garlica Murowana Experimental Station of University of Agriculture in Krakow, Poland. The experimental station is placed $270 \mathrm{~m}$ above sea level (latitude $\mathrm{N}=50^{\circ} 09^{\prime}$, longitude $\mathrm{E}=19^{\circ} 55^{\prime}$ ). Weather conditions such as mean monthly temperature and total monthly precipitation during the years 2005-2008 are given in Table 1.

The bushes were planted at the spacing of $1 \times 1 \mathrm{~m}$ in a field covered with black non-woven mulch. The randomized block experimental design was used with five replicates (four bushes per plot). The plants were irrigated during drought. The honeysuckle berries were collected fully ripened in several successive harvests (fruit were uniformly coloured and softened and they were easily separated from stalk). The determination of vitamin $\mathrm{C}$, anthocyanins and total soluble solids content (TSS), as well as titratable acidity was performed directly after harvest.

Total soluble solid content was determined by refractometer measurement (PN-EN 12143:2000), juice $\mathrm{pH}$ (potentiometric measurement according to PN-90/A-75101/06), titratable acidity according to PN-EN 12147:2000 expressed as equivalents of citric acid, L-ascorbic acid content - according to PN-A04019:1998, and anthocyanins by differentiated $\mathrm{pH}$ according to Giusti and Wrolstad (2000). The results obtained were subjected to analysis of variance, and means separation by Student $t$ test at $\mathrm{p}=0.05$.

\section{RESULTS AND DISCUSSION}

Mean monthly temperature and total monthly precipitation in 2005-2008 in Garlica Murowana were placed in Table 1. In spite of the noted low temperature $\left(-6^{\circ} \mathrm{C}\right)$ during the flowering period in 2007 , no injured flowers were observed (data not presented).

It was found that the number of days calculated from the beginning of flowering to the first fruit harvest was nearly the same in each year for both cultivars, and has changed depending on the year. The earliest fruit harvests was in 2007 - at the end of May (Tab. 2). In warmer climatic regions fruit harvest may take place even earlier, i.e. from 15 May, as reported for South Moravia by Řezniček (2007).

In successive years the length of the cropping periods was different for the honeysuckle cultivars. The longest period of fruit harvest was noted in 2006 in the 'Atut' cultivar (22 days), while the fruits of 'Duet' were collected for 18 days in 2007 (Fig. 1). In each year, 'Atut' began the vegetation, flowering and fruiting period earlier than 'Duet'. In the north part of the U.S. the beginning of fruit ripening took place about 18-28 June (Hummer 2006). Near the region of St. Petersburg, in Russia, fifteen

Table 1. Mean monthly temperature and total monthly precipitation in 2005-2008 in the Garlica Murowana Experimental Station

\begin{tabular}{|c|c|c|c|c|c|c|c|c|c|c|c|c|}
\hline Month & I & II & III & IV & $\mathrm{V}$ & VI & VII & VIII & IX & $\mathrm{X}$ & $\mathrm{XI}$ & XII \\
\hline Year & \multicolumn{12}{|c|}{ Mean monthly temperature $\left({ }^{\circ} \mathrm{C}\right)$} \\
\hline 2005 & -0.5 & -3.9 & 0.5 & 9.1 & 13.4 & 15.9 & 18.8 & 16.9 & 14.6 & 9.0 & 1.9 & -1.2 \\
\hline 2007 & 2.8 & 0.6 & 5.9 & 9.3 & 14.6 & 18.0 & 18.3 & 18.6 & 11.9 & 7.2 & 0.2 & -1.5 \\
\hline 2008 & 0.9 & 2.1 & 3.5 & 8.7 & 13.1 & 17.7 & 18.1 & 18.1 & 12.3 & 9.6 & 4.8 & 1.0 \\
\hline 2005 & 72.2 & 15.6 & 18.6 & 23.3 & 70.4 & 66.8 & 104.8 & 100.6 & 21.4 & 3.0 & 33.5 & 74.2 \\
\hline 2006 & 25.9 & 29.2 & 58.8 & 38.0 & 42.0 & 84.3 & 24.6 & 127.8 & 48.1 & 21.3 & 72.3 & 16.5 \\
\hline 2007 & 73.4 & 51.0 & 61.3 & 21.4 & 49.5 & 63.5 & 69.4 & 65.7 & 294.1 & 77.2 & 83.0 & 23.0 \\
\hline 2008 & 30.0 & 6.6 & 55.2 & 31.2 & 29.5 & 14.2 & 117.4 & 74.6 & 68.4 & 46.8 & 24.1 & 32.4 \\
\hline
\end{tabular}


Table 2. The phenophases of honeysuckle cultivars in 2005-2008

\begin{tabular}{|c|c|c|c|c|c|}
\hline Cultivar & Phenophases & 2005 & 2006 & 2007 & 2008 \\
\hline \multirow{2}{*}{ 'Atut' } & Beginning of flowering & April 19 & May 5 & April 16 & March 31 \\
\hline & Beginning of harvesting & June 6 & June 9 & May 26 & June 2 \\
\hline \multirow{2}{*}{ 'Duet' } & Beginning of flowering & April 21 & May 8 & April 19 & April 8 \\
\hline & Beginning of harvesting & June 8 & June 13 & May 29 & June 6 \\
\hline
\end{tabular}

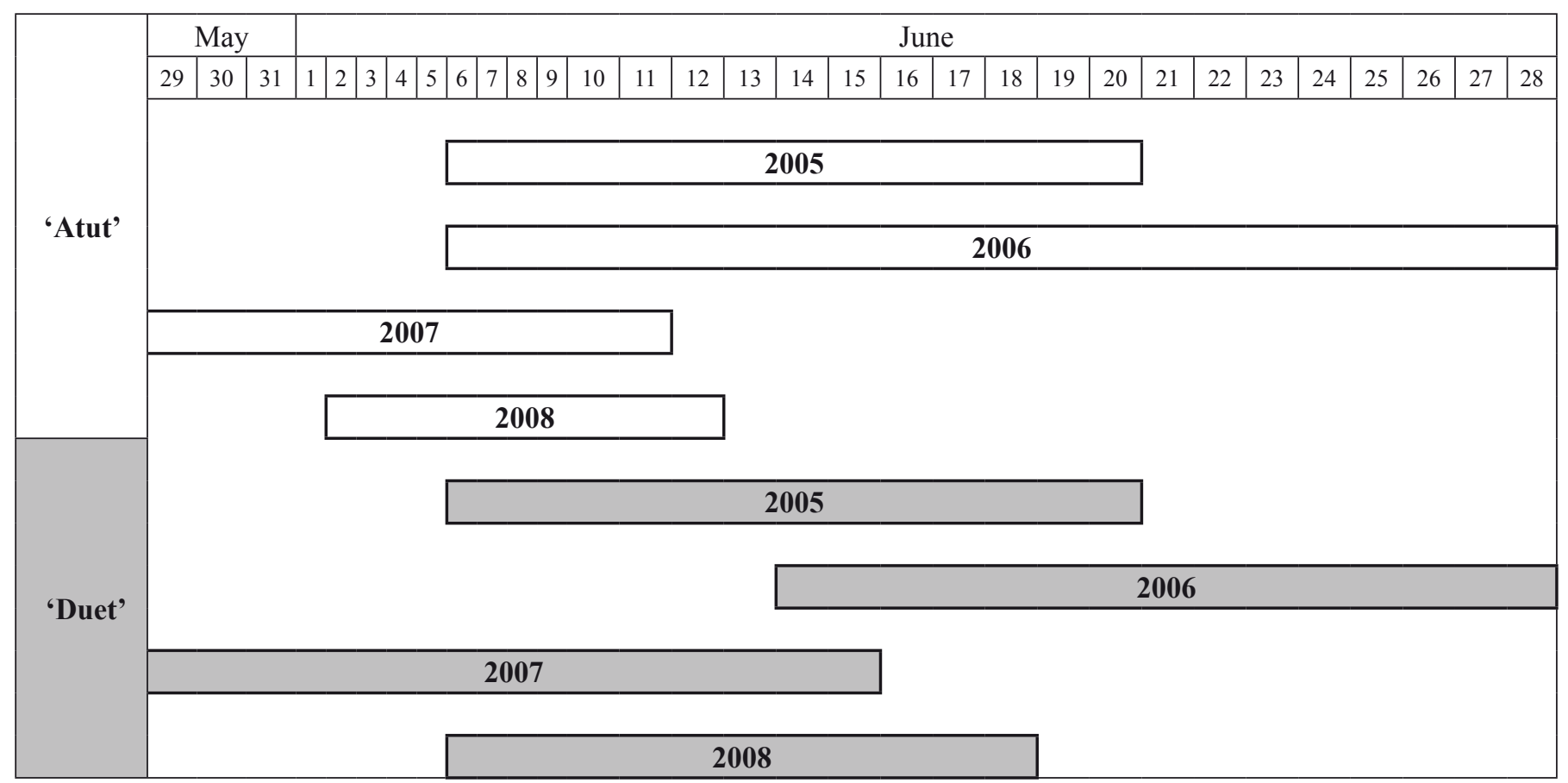

Figure 1. Period of cropping of two honeysuckle cultivars in 2005-2008 (first and last harvest)

cultivars of blue honeysuckle started to ripen in a similar season of the year, 12-28 June (Plekhanova 2000).

The blue honeysuckle bushes started cropping in 2005. Berries were collected several times because of successive ripening. The fruit of 'Atut' were collected six, seven, six and six times, whereas the fruit of 'Duet' were collected seven, six, eight and seven times, respectively, in the years 2005-2008. The marketable yield of 'Duet' fruit was higher than that of 'Atut' in each year of the experiment (Tab. 3). The fruit yield of 'Atut' calculated per bush ranged from $0.26 \mathrm{~kg}$ (2005) to $0.96 \mathrm{~kg}$ (2007), whereas the fruit yield of 'Duet' ranged from $0.34 \mathrm{~kg}$ (2005) to $1.24 \mathrm{~kg}$ (2008). Fruit dropping was very low and amounted to several percent of total fruit yield. In 2008, the fourth season of fruit bearing, fruit yield from one hectare of honeysuckle plantation ranged from 8 to $12 \mathrm{t} \mathrm{ha}^{-1}$ for 'Atut' and 'Duet', respectively. According to several authors, fruit yield from one bush can range from 2 to $6 \mathrm{~kg}$ (Plekhanova 2000, Hummer 2006).

Berries of 'Duet' were bigger (mass of one berry varied from 1.6 to $1.9 \mathrm{~g}$ ), whereas the mass of 'Atut' berry hardly achieved $1.06 \mathrm{~g}$ (Tab. 3). Fruit mass of other

Table 3. Marketable yield and mass of 100 berries of two honeysuckle cultivars

\begin{tabular}{|c|c|c|c|c|c|c|c|c|}
\hline \multirow{2}{*}{ Specification } & \multicolumn{4}{|c|}{$\begin{array}{c}\text { Marketable yield per plot } \\
(\mathrm{kg})\end{array}$} & \multicolumn{4}{|c|}{$\begin{array}{c}\text { Mass of } 100 \text { berries } \\
(\mathrm{g})\end{array}$} \\
\hline & 2005 & 2006 & 2007 & 2008 & 2005 & 2006 & 2007 & 2008 \\
\hline 'Atut' & $1.04 \mathrm{a}^{*}$ & $2.31 \mathrm{a}$ & $3.85 \mathrm{a}$ & $3.24 \mathrm{a}$ & $80.0 \mathrm{a}$ & $104.6 \mathrm{a}$ & $105.1 \mathrm{a}$ & $106.0 \mathrm{a}$ \\
\hline 'Duet' & $1.35 \mathrm{~b}$ & $2.87 \mathrm{~b}$ & $4.96 \mathrm{~b}$ & $4.94 \mathrm{~b}$ & $160.0 \mathrm{~b}$ & $190.6 \mathrm{~b}$ & $187.3 \mathrm{~b}$ & $168.0 \mathrm{~b}$ \\
\hline
\end{tabular}

*Means followed by the same letters do not differ significantly at $\mathrm{p}=0.05$ 
Table 4. Total soluble solids and titratable acidity of honeysuckle fruit

\begin{tabular}{|c|c|c|c|c|c|c|c|c|c|c|c|c|}
\hline \multirow[t]{2}{*}{ Specification } & \multicolumn{4}{|c|}{$\begin{array}{c}\text { Total soluble solids } \\
(\%)\end{array}$} & \multicolumn{4}{|c|}{ Juice $\mathrm{pH}$} & \multicolumn{4}{|c|}{$\begin{array}{l}\text { Titratable acidity } \\
\quad\left(\mathrm{g} 100 \mathrm{~g}^{-1}\right)\end{array}$} \\
\hline & 2005 & 2006 & 2007 & 2008 & 2005 & 2006 & 2007 & 2008 & 2005 & 2006 & 2007 & 2008 \\
\hline 'Atut' & $11.6 \mathrm{a}^{*}$ & $11.1 \mathrm{a}$ & $10.7 \mathrm{a}$ & $10.3 \mathrm{a}$ & $3.4 \mathrm{a}$ & $3.2 \mathrm{a}$ & $3.2 \mathrm{a}$ & $3.2 \mathrm{a}$ & $2.6 \mathrm{~b}$ & $3.0 \mathrm{~b}$ & $2.7 \mathrm{~b}$ & $3.1 \mathrm{~b}$ \\
\hline 'Duet' & $11.5 \mathrm{a}$ & $11.3 \mathrm{a}$ & $10.5 \mathrm{a}$ & $10.4 \mathrm{a}$ & $3.8 \mathrm{~b}$ & $3.4 \mathrm{~b}$ & $3.4 \mathrm{~b}$ & $3.4 \mathrm{~b}$ & $1.8 \mathrm{a}$ & $2.1 \mathrm{a}$ & $1.8 \mathrm{a}$ & $2.2 \mathrm{a}$ \\
\hline
\end{tabular}

*Explanations: see Table 3

Table 5. Vitamin C and anthocyanin content in the honeysuckle fruit of 'Atut' and 'Duet'

\begin{tabular}{|c|c|c|c|c|c|c|c|c|}
\hline \multirow[t]{2}{*}{ Specification } & \multicolumn{4}{|c|}{ 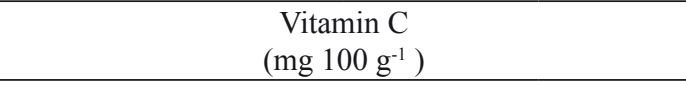 } & \multicolumn{4}{|c|}{$\begin{array}{c}\text { Anthocyanins } \\
\left(\mathrm{mg} 100 \mathrm{~g}^{-1}\right)\end{array}$} \\
\hline & 2005 & 2006 & 2007 & 2008 & 2005 & 2006 & 2007 & 2008 \\
\hline 'Atut' & $44.5 b^{*}$ & $35.9 \mathrm{a}$ & $34.3 \mathrm{a}$ & $35.6 \mathrm{a}$ & $202.0 \mathrm{a}$ & $235.4 \mathrm{~b}$ & $135.4 \mathrm{~b}$ & $136.8 \mathrm{~b}$ \\
\hline 'Duet' & $36.0 \mathrm{a}$ & $34.0 \mathrm{a}$ & $41.8 \mathrm{a}$ & $31.9 \mathrm{a}$ & $206.0 \mathrm{a}$ & $126.1 \mathrm{a}$ & $96.3 \mathrm{a}$ & $105.2 \mathrm{a}$ \\
\hline
\end{tabular}

*Explanations: see Table 3

Polish honeysuckle cultivars range from 0.88 to $1.03 \mathrm{~g}$ (Ochmian and Grajkowski 2007). Some authors reported that the mass of 100 berries could be slightly lower $(0.5$ -1.5 g) (Plekhanova 2000, Marková2001, Hummer 2006), whereas Thompson and Chaovanalikit (2003) inform that the mass of one berry may achieve $3 \mathrm{~g}$. According to Bors (2009), the mass of one berry of Canadian cultivars varied from 1.4 to $1.6 \mathrm{~g}$, and Russian cultivars from 0.5 to $0.8 \mathrm{~g}$. The berries of fruit mass above $1 \mathrm{~g}$ are regarded to be of dessert value. In this study, the fruit mass from early and last harvest 'Atut' and 'Duet' honeysuckle did not differ (data not published). In addition, Skupień et al. (2009) reported that berries of the 'Czarna' honeysuckle from the earlier harvests were bigger but less firm.

The total soluble solid (TSS) content in the fruit of both cultivars was not differentiated in the years of the study. The level of TSS in 'Atut' fruit ranged from 10.3 to $11.6 \%$, whereas in 'Duet' fruit, $10.4-11.5 \%$ (Tab. 4). The higher value of juice $\mathrm{pH}$ was determinate for 'Duet' fruit in each year of the study. The titratable acidity of 'Atut' berries was significantly higher compared to 'Duet', and total acid content achieved the value of $2.6 \mathrm{~g}$

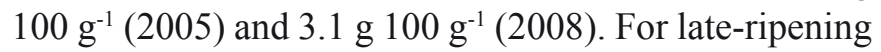
'Czarna' honeysuckle, a similar level of TSS and titratable acidity was noted (Ochmian and Grajkowski 2007). Plekhanova and Streltsyna (1998) determined that the titratable acidity of Lonicera fruit ranged from $2.7 \%$ to $4.8 \%$.

The honeysuckle fruit was found to be rich in vitamin C. Only in 2005 the content of vitamin C in 'Atut' fruit significantly exceeded the content of vitamin C in 'Duet' fruit, 44.5 and $36.0 \mathrm{mg} 100 \mathrm{~g}^{-1}$, respectively (Tab. 5). In the successive three years of the study the amounts of vitamin $\mathrm{C}$ in the fruit of the two cultivars did not differ from one another. Tanaka and Tanaka (1998) found the content of that compound on a similar level $(44.3 \mathrm{mg}$
$100 \mathrm{~g}^{-1}$ ). According to Hummer (2006), the content of L-ascorbic acid in the fruit of seven cultivars ranged

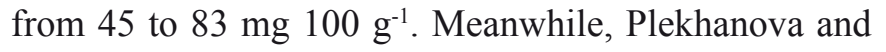
Streltsyna (1998) showed the great differences in the content of that vitamin depending on the cultivar (30.5 $-103.5 \mathrm{mg} 100 \mathrm{~g}^{-1}$ ). Marková (2001) revealed that vitamin $\mathrm{C}$ content may range from 20 to $170 \mathrm{mg} 100 \mathrm{~g}^{-1}$. Ochmian and Grajkowski (2007) have found much higher levels of vitamin C (55-106 mg $\left.100 \mathrm{~g}^{-1}\right)$ for Polish cultivars 'Wojtek', 'Zielona' and 'Czarna'. Skupień et al. (2007) have found smaller content of vitamin C (42.7 mg 100 $\left.\mathrm{g}^{-1}\right)$ in 'Zielona' honeysuckle fruit. Pauloviscová et al. (2009) indicated that ascorbic acid content in the edible honeysuckles is predominantly influenced by climatic conditions.

In the presented study the contents of anthocyanins in honeysuckle fruit were calculated in terms of cyanidin 3-glucosid (the predominant anthocyanin). Excluding the first year of the study, the anthocyanin content in 'Atut' berries was significantly higher than in 'Duet' fruit (Tab. 5). The highest amount of those pigments (235.4 $\mathrm{mg} 100 \mathrm{~g}^{-1}$ ) was determined in 'Atut' fruit in 2006. The chemical analysis carried out six months later revealed an increase of about $30 \%$ in the content of anthocyanins (data not published). Matuškovič et al. (2009) found a correlation between anthocyanins and ascorbic acid content in honeysuckle fruit; this type of correlation was year-dependant. These authors reported a high level of vitamin $\mathrm{C}$ and anthocyanins within Lonicera kamtschatica and their 22 clones (56.1 and $1221 \mathrm{mg}$ $100 \mathrm{~g}^{-1}$, respectively). Oszmiański et al. (1995), using HPLC, identified four anthocyanins in Lonicera kamtschatica fruit: the cyanidin derivatives as 3-glucoside, 3-rutinoside, 3.5-diglucoside and malvidin 3-glucoside. The major pigment, cyanidin 3-glucoside, accounted for $91 \%$ of the total pigment ( $332.4 \mathrm{mg} \%$ ) content. Skupien 
et al. (2009) reported that the late ripening berries of the 'Czarna' cultivar and seedling ' $\mathrm{N}$ ' showed an enhanced level of soluble solids and total polyphenols accompanied by a decrease of titratable acidity and L-ascorbic acid content. The blue honeysuckle fruit of the 'Zielona' cultivar showed a high amount of total acid (2.98 g 100

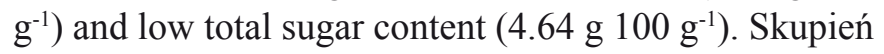
et al. (2007) identified anthocyanins as the predominating group (84.5\%) among phenolic compounds in 'Zielona' fruit at the level of $269.8 \mathrm{mg} 100 \mathrm{~g}^{-1}$. Most researchers reported high content of anthocyanins in honeysuckle fruit (in mg $100 \mathrm{~g}^{-1}$ ): 900-1400 (Marková 2001), 116-339 (Thompson and Chaovanlikit 2003), 690 (Lipecki et al. 2003), 321 (Frejnagel 2007), and 750-950 (Deineka et al. 2005). Hummer (2006) indicated the anthocyanin content for three cultivars (in mg $100 \mathrm{~g} \mathrm{~g}^{-1}$ ): 122 for 'Magadan', 172.5 for 'Sinajaptica' and 338.3 for 'Zamitsa'. Chaovanalikit et al. (2004) detected six anthocyanin in Lonicera fruit. Bąkowska-Barczak et al. (2007) revealed the presence of cyanidin 3-glucosid at the level of 1081 mg $100 \mathrm{~g}^{-1}$, but Paulovicsová et al. (2009) reported very low content of anthocyanins in Lonicera kamtschatica fruit.

\section{CONCLUSIONS}

1. Upon the beginning of flowering and harvesting, 'Atut' honeysuckle can be regarded as an earlier cultivar than 'Duet'.

2. A higher marketable yield and mass of berries was noted for the 'Duet' cultivar compared to the 'Atut' cultivar.

3. The fruit of 'Atut' contained higher amount of anthocyanins comparing to the 'Duet' cultivar, whereas the vitamin $\mathrm{C}$ and total soluble solid contents were at a similar level in fruit of both honeysuckle cultivars.

\section{REFERENCES}

AntalikovÁ M., MatušKovič J., ŠımKo J., 2007. Evaluating the behavior of chosen phenological phase of the honeysuckleedible (Lonicera kamtschatica (Sevast.) Pojark.). Vaccinium ssp. and Less Known Small Fruits: Cultivation and Health Benefit and COST 863 Euroberry Research: from Genomic to Sustainable Production, Quality and Health, Joint Meeting WG3\&4. Book of Abstracts: 105.

Arus L., Kask K., 2007. Edible honeysuckle (Lonicera caerulea var. edulis) - under utilized berry crop in Estonia. NJF Report. 3(1): 33-36.

Bąkowska-Barczak A.M., Marianchuk M., Kolodziejczyk P., 2007. Survey of bioactive components in Western Canadian berries. Can. J. Physiol. Pharmacol. 85, 11(1): 1139-1152.
Bors B., 2009. Blue Honeysuckle. http://www.usask.ca/ agriculture/plantsci/dom_fruit/articles/blue_honeysuckle. pdf.

Chaovanalikit A., Thompson M.M., Wrolstad R.E., 2004. Characterization and quantification of anthocyanins and polyphenolics in blue honeysuckle (Lonicera caerulea L.). J. Agric. Food Chem. 52(4): 848-852.

Deineka V., Srokopudov V., Deineka L., Shaposhnik E., Koltsov S., 2005. Anthocyanins from fruit of some plants of the Caprifoliaceae family. Chemistry of Natural Compounds 41(2): 162-164.

FrejNAGEL S., 2007. Comparison of polyphenolic composition of extracts from honeysuckle, chokeberries and green teaa short report. Pol. J. Food Nutr. Sci. 57(1): 83-86.

Giusti M.M., Wrolstad R.E., 2000. Unit F1.2.1-13. Anthocyanins. Characterization and Measurement with UV - Visible Spectroscopy. In: Current Protocols in Food Analytical Chemistry. R.E. Wrolstad (ed.). John Wiley \& Sons, NY.

Golis T., Gwozdecki J., 2007. Evaluation of honeysuckle (Lonicera sp.) cultivars in Poland. Vaccinium ssp. and Less Known Small Fruits: Cultivation and Health Benefit and COST 863 Euroberry Research: from Genomic to Sustainable Production, Quality and Health, Joint Meeting WG3\&4. Book of Abstracts: 69.

Gruia M.L., Oprea E., Gruia I., Negoita V., Farcasanu I.C., 2008. The antioxidant response induced by Lonicera caerulea berry. Extracts in Animals Bearing Experimental Solid Tumors, Molecules 13: 1195-1206.

Hummer K.E., 2006. Blue honeysuckle: a new berry crop for North America. J. Americ. Pomol. Soc. 60(1): 3-8.

Kawecki Z., Łojko R., Pilarek B., 2001. Mało znane rośliny sadownicze. UWM, Olsztyn.

LipeCKi J., JANisz A., SzEMBER E., 2003. Zawartość niektórych składników chemicznych w owocach roślin mało znanych. Folia Hort. Supl. 1: 224-226.

Malolepsza U., UrbaneK H., 2000. Flawonoidy roślinne jako związki biochemicznie czynne. Wiad. Bot. 44(3/4): 27-37.

MARKovÁ R., 2001. Study of vegetative, growing and economic character of genus Lonicera subsect. caerulea Rehd. Proc. $9^{\text {th }}$ Inter. Conf. of Horticulture, Lednice, 3-6 September: V. 1: $130-135$.

Máriássyová M., Šilhár S., Kovác M., 1999. New sources of anthocyanins. Agri-food quality II: Quality management of fruits and vegetables-from field to table. M. Hägg, R. Ahvenainen, A.M. Evers and K. Tiilikkala (eds). Special publication 229, Royal Society of Chemistry, Cambridge: 376.

Matuškovič J., Juríková T., Jurík I., Šimko J., Gazdík Z., 2009. The content of anthocyanins and ascorbic acid in the genofond of 22 clones of Lonicera kamtschatica (Sevast) Pojark. Gerda/25. Agricult. 55(2): 88-94.

Misaki Y. Mizutani Y., Itakura K., 2006. Inhibitory effect of blue honeysuckle juice on melanogenesis. Fragr. J. 34(8): 22-27.

Ochmian I., Grajkowski J., 2007. Wzrost i plonowanie trzech odmian jagody kamczackiej (Lonicera caerulea) na 
Pomorzu Zachodnim w pierwszych latach po posadzeniu. Rocz. AR Pozn. 383, Ogr. 41: 351-355.

Oszmiański J., Souquet J.M., Moutounet M., 1995. Antocyjany owoców borówki kamczackiej. Zesz. Nauk. AR we Wrocławiu, Technol. Żywn. 8(23): 67-72.

Paulovicsová B., Turianica I., Jurková T., Baloghová M., MatušKovič J., 2009. Antioxidant properties of selected less common fruit species. Lucrări ştiinţifice Zootehnie şi Biotechnologii 42(1): 608-614.

Plekhanova M.N., 1996. Blue Honeysuckle: a new berry from Russia. Pomona 29(I): 46-48.

Plekhanova M.N., 2000. Blue honeysuckle (Lonicera caerulea L.) - a new commercial berry for crop temperate climate: Genetic resources and breeding. Acta Hort. 538: 159-164.

Plekhanova M.N., Rostova N.N., 1994. Analysis of variation in morphological, anatomical an biochemical characteristics of Lonicera subsection Caerulea (Caprifoliaceae) by using the principal components method. Botanicheskii Zhurnal 79(2): 45-64.

Plekhanova M.N., Streltsyna S.A., 1998. Fruit chemical composition of Lonicera subsect. caerulea (Caprifoliaceae) species. Metsanduslikud-Uurimuset 30: 143-146.

ŘEZNIČEK V., 2007. Evaluation of the variability of a selected group of varietes of honeysuckle - Lonicera caerulea subs. edulis Turcz. Ex Freyn. Vaccinium ssp. and Less Known Small Fruits: Cultivation and Health Benefit and COST 863 Euroberry Research: from Genomic to Sustainable Production, Quality and Health, Joint Meeting WG3\&4. Book of Abstracts: 48.

Skupień K., Ochmian I., Grajkowski J., 2009. Influence of ripening time on fruit chemical composition of two blue honeysuckle cultigens. J. Fruit Ornam. Plant Res. 17(1): 101-111.

Skupień K., Oszmiański J., Ochman I., Grajkowski J., 2007. Characterization of selected physico-chemical features of blue honeysuckle fruit cultivar Zielona. Pol. J. Natur. Sci., Suppl. 4: 101-107.
Solovyeva L.V., Plekhanova M.N., 2003. Karyotype studies in blue honeysuckle species (Lonicera Subsect. Caeruleae, Caprifoliaceae). Cytol. Gen. 37(1): 34-42.

Svarcova I., Heinrich J., Valentova K., 2007. Berry fruits as a source of biologically active compounds: the case of Lonicera caerulea. Biomed. Pap. Med. Fac. Univ. Palacky Olomouc Czech Repub. 151(2): 163-174.

Tanaka T., Tanaka A., 1998. Chemical composition and characteristics of Haskapu berries in various cultivars and strains. J. Jap. Soc. Food Sci. Technol. 452 (2): 129-133.

Thompson M.M, Chaovanalikit A., 2003. Preliminary observation on adaptation and nutracelutical values of blue honeysuckle (Lonicera caerulea) in Oregon, USA. Acta Hort. 626: 65-72.

Zadernowski R., Naczyk M., Nesterowicz J., 2005. Phenolic acid profile in some small berries. J. Agric. Food Chem. 53(6): 2118-2124.

\section{OCENA PLONOWANIA ORAZ ZAWARTOŚĆ NIEKTÓRYCH SKŁADNIKÓW W OWOCACH SUCHODRZEWU SINEGO (LONICERA CAERULEA VAR. EDULIS TURCZ. FREYN.)}

Streszczenie: Doświadczenie prowadzono w latach 2005-2008 w Stacji Doświadczalnej Uniwersytetu Rolniczego w Krakowie, w Garlicy Murowanej. Oceniano plon, masę 100 jagód oraz zawartość w owocach kwasu askorbinowego, ekstraktu, antocyjanów, a także pH oraz kwasowość ogólną soku owoców. Wykazano, że odmiana 'Atut' wcześniej rozpoczynała wegetację, kwitnienie i owocowanie w porównaniu $z$ odmianą 'Duet'. Odmiana 'Duet' odznaczała się większym plonem handlowym i masą 100 jagód. W owocach odmiany 'Atut' wykazano większą zawartość antocyjanów, natomiast nie stwierdzono różnic w zawartości ekstraktu oraz witaminy $\mathrm{C}$ w owocach obu odmian.

Received December 14, 2009; accepted July 22, 2010 